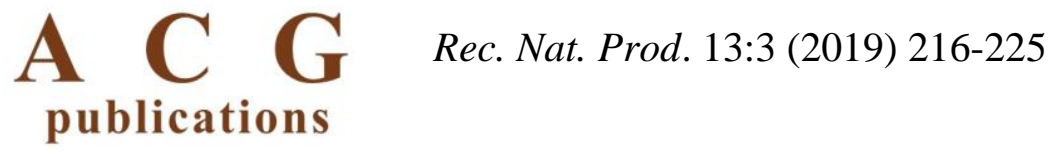

records of natural products

\title{
Inhibitory Effects of Metabolites Isolated \\ from Artemisia dracunculus L. Against the Human Carbonic Anhydrase I (hCA I) and II (hCA II)
}

\author{
Tuba Aydın $\odot^{1 *}$, Bayram Yurtvermez $\odot^{2}$, Murat Şentürk $\odot^{3}$, Cavit $\operatorname{Kazaz}^{\odot^{4}}$ and \\ Ahmet Çakır $\odot^{5}$ \\ ${ }^{1}$ Ağr İbrahim Çeçen University, Faculty of Pharmacy, Department of Pharmacognosy, 04100, Agri, \\ Türkiye \\ ${ }^{2}$ A $\breve{g r l}$ İbrahim Çeçen University, Institute of Science, 04100, Agri, Türkiye \\ ${ }^{3}$ Ağrl İbrahim Çeçen University, Faculty of Pharmacy, Department of Biochemistry, 04100, Agri, Türkiye \\ ${ }^{4}$ Atatürk University, Faculty of Science, Department of Chemistry, 25100, Erzurum, Türkiye \\ ${ }^{5}$ Kilis 7 Arallk University, Faculty of Science and Letters, Department of Chemistry, 79000, Kilis, Türkiye
}

(Received July 18, 2018; Revised September 13, 2018; Accepted September 20, 2018)

\begin{abstract}
Tarragon or Dragon's-wort (Artemisia dracunculus L.) is widely used as spice and in traditional medicine in various regions of the world. Inhibitory effects of the $n$-hexane, dichloromethane, ethanol and methanol extracts of the leaves of tarragon on the human carbonic anhydrase (hCA) I and II enzymes were investigated. Dichloromethane extract exhibited the strongest activity with lowest $\mathrm{IC}_{50}$ value $(0.020$ and $0.031 \mu \mathrm{g} / \mathrm{mL}$, respectively). The chromatographic studies on the dichloromethane extract of tarragon allowed the isolation of six known strong inhibitors of hCA isozymes as trans-anethole, stigmasterol, herniarin, $(2 E, 4 E)$ - $N$-isobutylundeca- 2,4 -dien-8,10diynamide, (2E,4E)-1-(piperidin-1-yl)undeca-2,4-diene-8,10-diyn-1-one and 1-(4'-methoxyphenyl)-1,2,3trihydroxypropane. The compound, 1-(4'-methoxyphenyl)-1,2,3-trihydroxypropane was isolated from tarragon for the first time in this study. Among the tested compounds, 1-(4'-methoxyphenyl)-1,2,3-trihydroxypropane showed the highest inhibitiory impact on both hCA isozymes. Also its $\mathrm{IC}_{50}$ values were found lower than positive control, acetazolamide.
\end{abstract}

Keywords: Artemisia dracunculus L.; 1-(4'-methoxyphenyl)-1,2,3-trihydroxypropane; enzyme inhibition; hCA I; hCA II. (C) 2019 ACG Publications. All rights reserved.

\section{Introduction}

Tarragon or dragon's-wort (Artemisia dracunculus L.), known as "tarhun" or "tarhon" in Anatolia is an edible perennial plant of Asteraceae family. It is a small shrubby and its aromatic leaves is used as spice in salads and vinegars [1,2]. Besides its tarragon and dragon's-wort common names, it is also named as "estragon, dragon sage-wort, false tarragon and dragon wormwood" [3,4]. Tarragon is distributed through the temperature regions of Asia, eastern and central Europe and western North America. This species is cultivated in the various region of the world such as southern Europe, Russia, Turkey as well as United

*Corresponding author: E-Mail: aydintuba25@gmail.com; Phone: +90-472-2159863 Fax: +90-472-2151182

The article was published by ACG Publications

http://www.acgpubs.org/journal/records-of-natural-products @ May-June 2019 EISSN:1307-6167

DOI: http://doi.org/10.25135/rnp.102.18.07.329 
States due to its usage as a spice in sauces and soups. Like many Artemisia species, A. dracunculus, an important medicinal and aromatic plant has been used in the treatment of various diseases in traditional medicine since centuries [1,5]. In traditional medicine in Anatolia, it possesses the common uses as digestive, diuretic, appetitive, emmenagogue, carminative, anthelmintic and antidiarrheal [5]. In the past, it was also used to malign ulcer treatment and plague epidemic in Armenia and it was used to for treat the epilepsy in traditional medicine in Europe [4]. Lately, there has been a growing interest on the biological activities of tarragon essential oils, extracts and dichloromethane extract active constituents in the literature. The results of the mentioned literature were showed that tarragon has various biological activities including the improving of Candida albicans infection [6], high antioxidant capacity [7], potent antileishmanial activity [8], strong antimicrobial activity [8], modulating of the immune system [9], effects on the glycemic control, insulin sensitivity and insulin secretion [10], analgesic and anti-inflammatory effects [11], antidiarrheal activity [12], anticancer effect [13], $\alpha$-amylase and $\alpha$-glucosidase inhibitory activities [14]. Russian tarragon and French tarragon are primary cultivars of A. dracunculus L. It is thought that the French tarragon is derived from Russian tarragon through the selection. The phytochemical content of tarragons collected from different geographical regions varies. Reason of this, polyploidies and differs cytogenetical are particularly widespread in tarragon. Accordingly, there is no joint approach about tarragon taxonomic classification in the present literature. In addition, some regional varieties of tarragon are distinguished by their essential oil content $[1,15,16]$. The principal seconder metabolites of $A$. dracunculus $L$. are pyhtoalexins, coumarins, chromones, phenylpropanoids, phenylpropenes, chalcones, alkamides, polyphenolics, acetylenes, monoterpenes alkamides, flavonoids and sesquiterpene lactones [1723]. The marker compound in the composition of A. dracunculus L. leaves is reported as herniarin [24]. The primary representative components of A. dracunculus L. are herniarin, pellitorine, dracumerin, scopoletin, chicoric acid, 5- $O$-caffeoylquinic acid, sakuranetin, davidigenin, 2',4'-dihydroxy-4methoxydihydrochalcone and 6-methoxycapillarisin [1]. The bioactive substances of A. dracunculus L. essential oils are phenolic acids, coumarins, flavonoids, polyacetylenes, sesquiterpenoids, vitamins and tannins. The primary compounds in essential oils were reported as trans-anethole, trans- $\beta$-ocimene, $c i s-\beta$ ocimene, limonene, sabinene, estragole, methyl eugenol, elemicin, isoelemicin, $\beta$-pinene, terpinen-4-ol, sabinene, 7-methoxycoumarin (herniarin) and $\beta$-ocimene $[1,24,25]$.

Carbonic anhydrase (CA) enzymes are metalloenzyme families that catalyzed rapidly conversion of $\mathrm{H}_{2} \mathrm{O}$ and $\mathrm{CO}_{2}$ to $\mathrm{H}^{+}$and $\mathrm{HCO}_{3}^{-}$[26]. CA enzymes are determined in different tissues where they attend various significant biochemical activities such as $\mathrm{CO}_{2}$ and ion transfer, bone resorption, respiratory, electrolytic secretion, acid-base balance, ureagenesis, lipogenesis and gluconeogenesis [26, 27]. Many CA enzymes are significant therapeutically targets with the properties to be activated/inhibited in the treatment of disorder such as epilepsy, glaucoma, osteoporosis, cancer, edema and obesity [26, 28]. Our research groups recently explored some phenolic compounds such as salicylates, catechol, resorcinol and their derivatives as CA enzyme inhibitors/activators $[29,30]$.

Medicinal and aromatic plants have been assumed as important pharmaceutical materials as an alternative to synthetic pharmaceuticals. Hence, in the current research, we aimed to investigate the inhibitory activities of $n$-hexane, dichloromethane, ethanol and methanol extracts and its six known constituents isolated by column chromatography from A. dracunculus L. on the hCA I and II isozymes.

\section{Materials and Methods}

\subsection{Plant and Chemical Materials}

Above-ground parts of A. dracunculus L. was purchased from Tiryaki Baharat (Nurs Lokman Hekim) (Erzurum, Turkey) in April 2015. The pure organic solvents were purchased from Tekkim, Fluka and Sigma. Thin layer chromatography (TLC) were applied on silica gel 60F-254 and silica gel 60. The stains on TLC were displayed by $\mathrm{UV}_{365}, \mathrm{UV}_{254}$, spraying (1\% vanillin- $\left.\mathrm{H}_{2} \mathrm{SO}_{4}\right)$ and heating $\left(105{ }^{\circ} \mathrm{C}\right)$. Column chromatography (CC) was applied by silica gel (200-400 and 70-230). The FT-IR (4000 and 400 $\left.\mathrm{cm}^{-1}\right)$ spectra were registered by Nicolet iS10 FT-IR, NMR $\left({ }^{1} \mathrm{H}\right.$ and $\left.{ }^{13} \mathrm{C}\right)$ spectra of isolated substances were registered by Bruker $400\left({ }^{1} \mathrm{H}: 400 \mathrm{MHz} ;{ }^{13} \mathrm{C}: 100 \mathrm{MHz}\right)$ spectrometer. $\mathrm{CDCl}_{3}$ was used as solvent, and tetramethylsilane (TMS) was used as an interior standard for the NMR assays. $\delta(\mathrm{ppm})$ relative to an interior standard, $J(\mathrm{~Hz})$. 


\subsection{Extraction and Isolation Procedures}

In order to determine the extracts exhibiting the strongest enzyme inhibitory effect of the $A$. dracunculus, the powdered above-ground parts of plant (50 g each ones) were individually extracted with $n$-hexane, dichloromethane, ethanol and methanol $(500 \mathrm{~mL}, 24 \mathrm{~h})$ at room temperature for five times. The extracts were concentrated at low temperature and pressure by a rotary evaporator. The amounts of $n$ hexane, dichloromethane, ethanol and methanol extracts were 4.0, 5.2, 9.6 and 10.0 respectively as $\mathrm{g}$.

Inhibition effects of the extracts were determined on the isozymes (hCA I and hCA II) (Table 1). When the results are examined, the $\mathrm{IC}_{50}$ values of the extracts were very close to each other on the hCA isozymes. However, the dichloromethane extract was preferred to purify the active compound and/or compounds due to its the lowest $\mathrm{IC}_{50}$ values. Hence, the dichloromethane extract was subjected to column and thin layer chromatography to isolate bioactive component and/or components from A. dracunculus $\mathrm{L}$. For this purpose, powdered samples of A. dracunculus $\mathrm{L}$. (1.0 kg) were extracted with dichloromethane (5 $\mathrm{x} 2 \mathrm{~L})$ at room temperature. The extract was concentrated at low temperature and pressure by a rotary evaporator and weighed $(52 \mathrm{~g})$. It was exposed to silica gel CC (360 g, 70-230) eluting with $\mathrm{CH}_{2} \mathrm{Cl}_{2}$ : $\mathrm{EtOAc}$ $(7: 3, \mathrm{v} / \mathrm{v})$ and partitioned into five fractions (Fr.1-Fr.5). Fraction 1 was again subjected to $\mathrm{CC}$ on a silica gel column (70 g, 70-230 mesh) using $n$-hexane:Et ${ }_{2} \mathrm{O}(9: 1, \mathrm{v} / \mathrm{v})$ to obtained compound 1 (7 mg). Likewise, the Fr.2 was repeatedly subjected to $\mathrm{CC}$ on a silica gel column by EtOAc: $n$-hexane $(3: 7, \mathrm{v} / \mathrm{v})$ to obtained compounds $2(54 \mathrm{mg}), \mathbf{3}(970 \mathrm{mg}), \mathbf{4}(18 \mathrm{mg})$ and $\mathbf{5}(419 \mathrm{mg})$. Compound $\mathbf{6}(15 \mathrm{mg})$ was isolated over silica gel column chromatography (100 g, 70-230 mesh) from Fr.5 eluting with $\mathrm{CHCl}_{3}$ :acetone (9:1, v/v).

Table 1. IC $_{50}$ values of the A. dracunculus extracts against hCA I and hCA II

\begin{tabular}{|c|c|c|}
\hline & \multicolumn{2}{|c|}{$\mathrm{IC}_{50}(\mu \mathrm{g} / \mathrm{mL})$} \\
\hline Extracts & hCA I & hCA II \\
\hline$n$-Hexane & $0.031 \pm 0.0005$ & $0.041 \pm 0.0006$ \\
\hline Dichloromethane & $0.020 \pm 0.0003$ & $0.031 \pm 0.0005$ \\
\hline Ethanol & $0.031 \pm 0.0004$ & $0.045 \pm 0.0006$ \\
\hline Methanol & $0.025 \pm 0.0003$ & $0.040 \pm 0.0006$ \\
\hline Acetazolamide & $1.652 \pm 0.0330$ & $0.016 \pm 0.0001$ \\
\hline
\end{tabular}

The spectroscopic data of the isolated compounds are given in below.

trans-Anethole (1): White crystals. IR (Solid): $\left(\mathrm{cm}^{-1}\right) 2957(-\mathrm{CH}), 1508(\mathrm{C}-\mathrm{C}), 1241(\mathrm{C}-\mathrm{O}) .{ }^{1} \mathrm{H}$ NMR $(\delta$, ppm) $\left(\mathrm{CDCl}_{3}\right): 7.29(d, J=8.68 \mathrm{~Hz}, \mathrm{H}-3$ and H-5), $6.87(d, J=8.68 \mathrm{~Hz}, \mathrm{H}-2$ and $\mathrm{H}-6), 6.38(d, J=15.8 \mathrm{~Hz}, \mathrm{H}-$ $\left.1^{\prime}\right), 6.08-6.17\left(m, \mathrm{H}-2^{\prime}\right), 3.80\left(s, \mathrm{OCH}_{3}\right), 1.89\left(d d, J_{I}=13.2 \mathrm{~Hz}, J_{2}=1.56 \mathrm{~Hz}\right.$ and $\left.1.48 \mathrm{~Hz}, \mathrm{H}-3^{\prime}\right) .{ }^{13} \mathrm{C}-\mathrm{NMR}(\delta$, ppm) $\left(\mathrm{CDCl}_{3}\right)$ : 158.6 (1), 130.9 (1'), 130.4 (3 and 5), 126.9 (4), 123.5 (2'), 113.9 (2 and 6), $55.3\left(\mathrm{OCH}_{3}\right)$, $18.4\left(3^{\prime}\right)$.

Stigmasterol (2): White needle crystal. IR (solid): $\left(\mathrm{cm}^{-1}\right) 3290(\mathrm{OH}), 2930(\mathrm{CH}), 1480(\mathrm{C}=\mathrm{C}), 1050$ (C-O). ${ }^{1} \mathrm{H}$ NMR $(\delta, \mathrm{ppm})\left(\mathrm{CDCl}_{3}\right): 5.36(m, \mathrm{H}-6), 5.17(d d, J=15.14 \mathrm{~Hz}, J=8.60 \mathrm{~Hz}, \mathrm{H}-22), 5.03\left(d d, J_{l}=15.15 \mathrm{~Hz}\right.$, $\left.J_{2}=8.72 \mathrm{~Hz}, \mathrm{H}-23\right), 3.54$ ( $\left.m, \mathrm{H}-3\right), 2.28$ ( $\left.m, \mathrm{H}-4\right), 1.01$ ( $\left.s, \mathrm{H}-19\right), 0.93(d, \mathrm{H}-21), 0.84(t, J=10.32 \mathrm{~Hz} \mathrm{H}-29)$, $0.71(d, J=7.33 \mathrm{~Hz}, \mathrm{H}-18) .{ }^{13} \mathrm{C}$ NMR $(\delta, \mathrm{ppm})\left(\mathrm{CDCl}_{3}\right): 140.7(5), 138.3(22), 129.2(23), 121.7(6), 71.8$ (3), 56.7 (14), 55.9 (17), 51.2 (24), 50.1 (9), 42.3 (4), 42.2 (13), 40.5 (20), 39.7 (12), 37.2 (1), 36.1 (10), 31.9 (8 and 25), 31.6 (2 and 7), 29.1 (16), 26.0 (28), 24.3 (15), 21.2 (11), 21.0 (21), 19.4 (19), 19.0 (26), 18.8 (27), 12.1 (29), $12.0(18)$.

Herniarin (3): White powder crystal. IR (solid): $\left(\mathrm{cm}^{-1}\right) 3100(-\mathrm{CH}), 1700(\mathrm{C}=\mathrm{O}), 1600-1250(\mathrm{C}=\mathrm{C}), 1100$ (C-O). ${ }^{1} \mathrm{H}$ NMR $(\delta, \mathrm{ppm})\left(\mathrm{CDCl}_{3}\right): 7.63(d, J=9.48 \mathrm{~Hz}, \mathrm{H}-4), 7.36(d, J=8.60 \mathrm{~Hz}, \mathrm{H}-5), 6.83\left(d d, J_{l}=11.04\right.$ $\left.\mathrm{Hz}, J_{2}=6.12 \mathrm{~Hz}, \mathrm{H}-6\right), 6.78(d, J=2.36 \mathrm{~Hz}, \mathrm{H}-8), 6.22(d, J=9.48 \mathrm{~Hz}, \mathrm{H}-3), 3.85\left(s, \mathrm{OC}_{3}\right) .{ }^{13} \mathrm{C}$ NMR $(\delta$, 
ppm) $\left(\mathrm{CDCl}_{3}\right): 162.8$ (7), 161.1 (2), 155.8 (9), 143.4 (4), 128.7 (5), 113.0 (3), 112.5 (6), 100.8 (8 and 10), $55.7\left(\mathrm{OCH}_{3}\right)$.

(2E,4E)-N-isobutylundeca-2,4-dien-8,10-diynamide (4): Brownish amorphous solid. IR (solid): ( $\left.\mathrm{cm}^{-1}\right) 3300$ $(\mathrm{NH}), 2910(\mathrm{CH}), 2190(\mathrm{C} \equiv \mathrm{C}), 1610(\mathrm{C}=\mathrm{O}), 1520(\mathrm{C}=\mathrm{C}) .{ }^{1} \mathrm{H}$ NMR $(\delta, \mathrm{ppm})\left(\mathrm{CDCl}_{3}\right): 7.18\left(d d, J_{I}=15.02\right.$ $\left.\mathrm{Hz}, J_{2}=10.76 \mathrm{~Hz}, \mathrm{H}-3\right), 6.20\left(d d, J_{I}=15.14 \mathrm{~Hz}, J_{2}=10.76 \mathrm{~Hz}, \mathrm{H}-4\right), 6.06(m, \mathrm{H}-5), 5.84(d, J=15.04 \mathrm{~Hz}, \mathrm{H}-$ 2), $3.16\left(t, J=6.40 \mathrm{~Hz}, \mathrm{H}-1^{\prime}\right), 2.4\left(m, \mathrm{H}-6\right.$ and H-7), $2.00(\mathrm{~s}, \mathrm{H}-11), 1.87$ ( $\left.m, \mathrm{H}-2^{\prime}\right), 0.92$ ( $d, J=6.68 \mathrm{~Hz}, \mathrm{H}-3$ ', $\left.\mathrm{H}-4^{\prime}\right) .{ }^{13} \mathrm{C} \operatorname{NMR}(\delta, \mathrm{ppm})\left(\mathrm{CDCl}_{3}\right): 166.2(1), 140.3$ (3), 139.0 (5), 129.8 (4), $123.2(2), 76.9$ (8), 68.2 (9), $65.4(10), 65.0(11), 47.0\left(1^{\prime}\right), 31.3(6), 28.6\left(2^{\prime}\right), 20.1$ (3' and 4'), 18.8 (7).

(2E,4E)-1-(piperidin-1-yl)undeca-2,4-diene-8,10-diyn-1-one (5): Brownish amorphous solid. IR (solid): $\left(\mathrm{cm}^{-1}\right) 2910(\mathrm{CH}), 2200(\mathrm{C} \equiv \mathrm{C}), 1610(\mathrm{C}=\mathrm{O}), 1520(\mathrm{C}=\mathrm{C}) .{ }^{1} \mathrm{H}$ NMR $(\delta, \mathrm{ppm})\left(\mathrm{CDCl}_{3}\right): 7.16\left(d d, J_{I}=14.81\right.$ $\left.\mathrm{Hz}, J_{2}=10.84 \mathrm{~Hz}, \mathrm{H}-3\right), 6.28(d, J=14.81, \mathrm{H}-2), 6.21\left(d d, J_{l}=15.15 \mathrm{~Hz}, J_{2}=10.68 \mathrm{~Hz}, \mathrm{H}-4\right), 5.98(d t$, $\left.J_{I}=15.09 \mathrm{~Hz}, J_{2}=3.64 \mathrm{~Hz}, \mathrm{H}-5\right), 3.56$ (br.s, H-1'), 3.45 (br.s, H-5'), 2.34 ( $m, \mathrm{H}-6$ and H-7), 1.99 (s, H-11), $1.62\left(m, \mathrm{H}-4^{\prime}\right), 1.54\left(m, \mathrm{H}-2^{\prime}\right), 1.26\left(m, \mathrm{H}-3{ }^{\prime}\right) .{ }^{13} \mathrm{C} \mathrm{NMR}(\delta, \mathrm{ppm})\left(\mathrm{CDCl}_{3}\right): 165.3(1), 141.8(3), 138.3(5)$, 130.3 (4), $120.0(2), 77.0(8), 68.2$ (9), 65.4 (10), $65.1(11), 46.8\left(5^{\prime}\right), 43.1\left(1^{\prime}\right), 31.2(6), 26.7$ (3'), 25.6 (4'), $24.6\left(2^{\prime}\right), 18.8(7)$.

1-(4'-methoxyphenyl)-1,2,3-trihydroxypropane (6): Yellowish oily liquid. $[\alpha]_{D}^{25}-260^{\circ}\left(\mathrm{c}=0.1, \mathrm{CH}_{2} \mathrm{Cl}_{2}\right)$. IR (solid): $\left(\mathrm{cm}^{-1}\right) 3390(\mathrm{OH}), 2924(\mathrm{CH}), 1510(\mathrm{C}=\mathrm{C}), 1247(\mathrm{C}-\mathrm{O}) .{ }^{1} \mathrm{H}$ NMR $(\delta, \mathrm{ppm})\left(\mathrm{CDCl}_{3}\right): 7.33(d$, $\left.J=6.80 \mathrm{~Hz}, \mathrm{H}-2^{\prime}, \mathrm{H}-6^{\prime}\right), 6.93$ ( $\left.d, J=5.84 \mathrm{~Hz}, \mathrm{H}-3^{\prime}, \mathrm{H}-5^{\prime}\right), 4.81$ ( $\left.d, J=5.64 \mathrm{~Hz}, \mathrm{H}-1\right), 4.00(m, \mathrm{H}-2), 3.82(s$, $\left.\mathrm{OCH}_{3}\right), 3.70\left(d d, J_{I}=11.32, J_{2}=7.32 \mathrm{~Hz}, \mathrm{H}-3 \mathrm{a}\right), 3.62\left(d d, J_{I}=11.30, J_{2}=3.56 \mathrm{~Hz}, \mathrm{H}-3 \mathrm{~b}\right) .{ }^{13} \mathrm{C}$ NMR $(\delta, \operatorname{ppm})$ $\left(\mathrm{CDCl}_{3}\right)$ : $159.5\left(4^{\prime}\right), 131.6\left(1^{\prime}\right), 127.79\left(2^{\prime}\right.$ and $\left.6^{\prime}\right), 114.0$ (3' and 5'), $74.8(2), 74.1(1), 55.3\left(\mathrm{OCH}_{3}\right), 46.4$ (3).

\subsection{Purification of hCA I and II Isozymes by Affinity Chromatography}

Erythrocytes were isolated from fresh human blood got from the Ataturk University Blood Centre. The samples were centrifuged $(15 \mathrm{~min}, 1500 \mathrm{rpm})$ and the buffy coat and plasma were staved. The red blood cells were purified, cleaned $(\mathrm{NaCl}, 0.9 \%)$ and hemolyzed (ice-cold water, $1.5 \mathrm{v})$. The intact cells and ghost were staved using centrifuge $(20.000 \mathrm{rpm}, 30 \mathrm{~min})$. The hemolysate $\mathrm{pH}$ was regulated as 8.7 (Tris) [31]. The hemolysate was carried out to the made-up sepharose 4B-tyrosine-sulfanylamide affinity column equalized by $25 \mathrm{mM}$ Tris- $\mathrm{HCl} / 0.1 \mathrm{M} \mathrm{Na}_{2} \mathrm{SO}_{4}(\mathrm{pH} 8.7)$. The affinity gel was cleaned $(25 \mathrm{mM}$ Tris- $\mathrm{HCl} / 22$ $\mathrm{mM} \mathrm{Na}_{2} \mathrm{SO}_{4}, \mathrm{pH}$ 8.7). The hCA I and II were eluted by $1 \mathrm{M} \mathrm{NaCl} / 25 \mathrm{mM} \mathrm{Na}_{2} \mathrm{HPO}_{4}(\mathrm{pH} 6.3)$ and $0.1 \mathrm{M}$ $\mathrm{CH}_{3} \mathrm{COONa} / 0.5 \mathrm{M} \mathrm{NaClO}_{4}$ (pH 5.6), respectively (Table 2). All of processes were applied at temp. $4{ }^{\circ} \mathrm{C}$ [31].

Table 2. Purification process for hCA I and II isozymes by a Sepharose-4B-aniline-sulfanilamide affinity CC.

\begin{tabular}{lcccccccc}
\hline $\begin{array}{l}\text { Purification } \\
\text { steps }\end{array}$ & $\begin{array}{c}\text { Activity } \\
(\mathbf{E U} / \mathbf{m L})\end{array}$ & $\begin{array}{c}\text { Total } \\
\text { volume } \\
(\mathbf{m L})\end{array}$ & $\begin{array}{c}\text { Protein } \\
(\mathbf{m g} / \mathbf{m L})\end{array}$ & $\begin{array}{c}\text { Total } \\
\text { protein } \\
(\mathbf{m g})\end{array}$ & $\begin{array}{c}\text { Total } \\
\text { activity } \\
(\mathbf{E U})\end{array}$ & $\begin{array}{c}\text { Specific } \\
\text { activity } \\
(\mathbf{E U} / \mathbf{m g})\end{array}$ & $\begin{array}{c}\text { Yield } \\
(\boldsymbol{\%})\end{array}$ & $\begin{array}{c}\text { Purification } \\
\text { factor }\end{array}$ \\
\hline $\begin{array}{l}\text { Hemolysate } \\
\text { hCA I }\end{array}$ & 160 & 34 & 18.12 & 616.08 & 5440 & 8.83 & 100 & 1 \\
& 480 & 6 & 0.50 & 3.0 & 2880 & 960 & 52.94 & 108.72 \\
hCA II & 855 & 4 & 0.14 & 0.56 & 3420 & 6107.14 & 62.87 & 691.63 \\
\hline
\end{tabular}

\subsection{Activity of human CA I and II Isozymes}

CA isozymes activities were analysed by the change at $348 \mathrm{~nm}$ absorbance from 4nitrophenylacetate to 4-nitrophenylate ion by spectrophotometer (Shimadzu) according to the procedure previously identified $\left(3 \mathrm{~min}, 25^{\circ} \mathrm{C}\right)[32]$. A reference measuring was determined at the similar conditions without enzyme solvents. The inhibition activities of A. dracunculus pure substances were investigated. All 
substances were assayed three times at every concentration. Inhibitor concentrations were applied at different rates. Acetazolamide was used as the reference molecule (Fig. 1). The activity of control cuvette without inhibitor was taken as $100 \%$. hCA activity was assayed with method of Verpoorte [32]. This method was applied to hCA I and II isozymes with minor modifications. NPA ( $3 \mathrm{mM})$ was used as a substrate.

\section{Results and Discussion}

\subsection{Chemical Composition of A. dracunculus}

Silica gel CC and TLC studies on the dichloromethane extract, which showed the strongest inhibitory effects on hCA I and II isozymes were allowed the isolation of six known compounds, two phenylpropanoids ( $\mathbf{1}$ and $\mathbf{6}$ ), one steroid (2), one coumarin (3) and two alkylamides (4 and $\mathbf{5})$. The chemical structures of the compounds as trans-anethole (1), stigmasterol (2), herniarin (3), (2E,4E)- $N$ isobutylundeca-2,4-dien-8,10-diynamide (4) (2E,4E)-1-(piperidin-1-yl)undeca-2,4-diene-8,10-diyn-1-one (5) and 1-(4'-methoxyphenyl)-1,2,3-trihydroxypropane (6) were determined by IR, ${ }^{1} \mathrm{H}-\mathrm{NMR}$ and ${ }^{13} \mathrm{C}-\mathrm{NMR}$ spectroscopic methods (Figure 1). For their characterization also 1D-NMR (DEPT) and 2D-NMR methods $\left({ }^{1} \mathrm{H}^{1} \mathrm{H}\right.$ COSY, HMQC and HMBC) were used.<smiles>C/C=C/c1ccc(OC)cc1</smiles>

(1)<smiles>COc1ccc2ccc(=O)oc2c1</smiles>

(3)

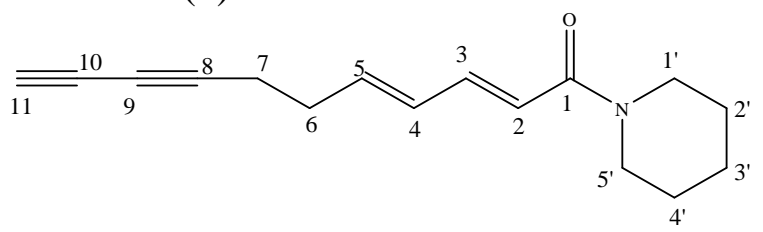

(5)

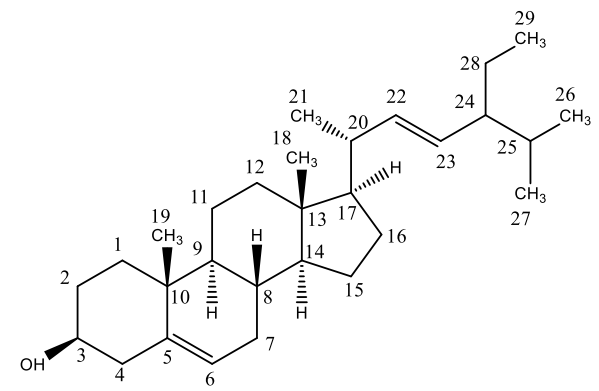

(2)

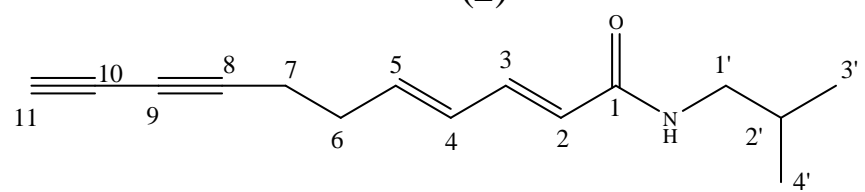

(4)

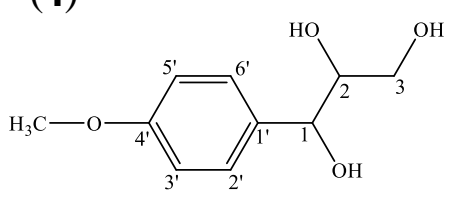

(6)

Figure 1. The chemical structures of the tarragon compounds 1-6

Previous reports demonstrated that alkylamides such as pellitorine, neopellitorine A, neopellitorine $\mathrm{B}$, undeca-2E,4E-dien-8,10-dynoic acid isobutylamide (4) and undeca-2E,4E-dien-8,10-dynoic acid piperidylamide (5) are the characteristic metabolites of A. dracunculus, besides herniarin (3), which is the characteristic and major metabolite. [1,5,14,16]. As shown in Figure 1 , in the current study, two alkylamides, undeca-2E,4E-dien-8,10-dynoic acid isobutylamide (4) and undeca-2E,4E-dien-8,10-dynoic acid piperidylamide (5) were isolated. Whereas various phenylpropanoids were reported from the $A$. dracunculus [1,5,15], 1-(4'-methoxyphenyl)-1,2,3-trihydroxypropane (6) was characterized from the $A$. dracunculus for the first time in this study and previously the compound $\mathbf{6}$ was reported from Illicium verum fruits [33]. 


\section{2. hCA Inhibitory effects of the A. dracunculus Compounds}

A. dracunculus is an edible, medicinal and aromatic plant species and it has various beneficial medical properties. Therefore, it has been used in the treatment of various diseases in traditional medicine in the different regions of the world since centuries [1,5]. A. dracunculus extract and some pure metabolites have also various in vivo and in vitro pharmacological activities such as antibacterial, antimicrobial, antiplatelet, antifungal, anti-inflammatory, antidiabetic, hepatoprotective, gastroprotective and anticonvulsant [1,4,20,34-38]. Many studies have revealed the therapeutic potentials of A. dracunculus $[22,39,40]$. However, in the literature, there was no study related to the carbonic anhydrase inhibition of $A$. dracunculus. For this reason, this study was aimed to attract the interest on A. dracunculus L. introducing new biological properties of its extracts and pure metabolites.

Hence, enzyme inhibitor potentials of methanol, ethanol, dichloromethane and $n$-hexane extracts of A. dracunculus L. and all isolating compounds were investigated on human CA I and II isozymes by comparing of their $\mathrm{IC}_{50}$ values for the first time in the current research. The present results demonstrated that the pure metabolites and extracts of $A$. dracunculus $\mathrm{L}$. were exhibited various inhibitions on the human CA I and II isozymes (Table 1). $\mathrm{IC}_{50}$ values for the extracts tested were given as $\mu \mathrm{g} / \mathrm{mL}$. When the $\mathrm{IC}_{50}$ values of the extracts were compared, they exhibited the approximate value enzyme inhibitory activities (Table 1). The most effective extract was found to be dichloromethane extract for both hCA I and hCA II with the lowest IC I0 $_{50}$ values, $0.020 \mu \mathrm{g} / \mathrm{mL}$ and $0.031 \mu \mathrm{g} / \mathrm{mL}$ on hCA I and II isozymes, respectively. These results suggested that dichloromethane extract as well as other extracts of A. dracunculus has the hCA enzymes inhibitor potentials. Hence, dichloromethane extract, the most effective extract on the hCA isozymes was subjected to chromatographic studies to isolate active compounds. trans-Anethole (1), stigmasterol (2), herniarin (3), (2E,4E)- $N$-isobutylundeca-2,4-dien-8,10-diynamide (4) (2E,4E)-1(piperidin-1-yl)undeca-2,4-diene-8,10-diyn-1-one (5) and 1-(4'-methoxyphenyl)-1,2,3-trihydroxypropane (6) were isolated from dichloromethane extract of A. dracunculus and these compounds tested for enzyme inhibitory activities on the hCA I and II isozymes (Table 3). As shown in Table 3, the pure compounds 1-6 showed various enzyme inhibitory activities with $0.17-486.2 \mu \mathrm{M}$ and $0.16-123.4 \mu \mathrm{M}$ of the $\mathrm{IC}_{50}$ values on hCA I and II isozymes, respectively. Among the pure A. dracunculus metabolites, the compound 6, 1-(4'methoxyphenyl)-1,2,3-trihydroxypropane showed the highest inhibitory effect on the both CA isozymes and the $\mathrm{IC}_{50}$ values of the compound on hCA I and II isozymes were lower than positive control acetazolamide. Furthermore, all A. dracunculus compounds were found to be more effective on the hCA-I isozymes (Table 3). Whereas, trans-anethole (1), is the major component of A. dracunculus volatiles was determined as least effective compound.

Table 3. $\mathrm{IC}_{50}$ values obtained from regression analysis graphs for hCA I and II.

\begin{tabular}{lcc}
\hline & \multicolumn{2}{c}{$\mathbf{I C}_{\mathbf{5 0}}(\boldsymbol{\mu M})$} \\
\hline Compounds & hCA I & hCA II \\
\hline $\mathbf{1}$ & $486.2 \pm 3.972$ & $123.4 \pm 1.730$ \\
$\mathbf{2}$ & $9.630 \pm 0.096$ & $8.770 \pm 0.131$ \\
$\mathbf{3}$ & $22.70 \pm 0.212$ & $29.50 \pm 0.413$ \\
$\mathbf{4}$ & $15.80 \pm 0.142$ & $11.20 \pm 0.008$ \\
$\mathbf{5}$ & $8.650 \pm 0.129$ & $8.960 \pm 0.125$ \\
$\mathbf{6}$ & $0.170 \pm 0.0025$ & $0.160 \pm 0.002$ \\
Acetazolamide & $72.50 \pm 1.0875$ & $0.730 \pm 0.011$ \\
\hline
\end{tabular}

Carbonic anhydrase enzyme reversibly catalyzes $\mathrm{CO}_{2}$ and $\mathrm{H}_{2} \mathrm{O}$ into protons and bicarbonate ions. This enzyme plays an important role in the regulation of fluid balance and $\mathrm{pH}$ in different section of living organisms. The transfering of the bicarbonate ions and protons generated in the eyes and kidneys influence the water content of cells. When there is a building up of fluid to maintain the shape of eyes, this fluid can damage the eye, called as glaucoma on the optic nerve in the eye by applying a pressure. In recent years, inhibitors of carbonic anhydrase enzyme in particular hCA II isozymes are used as drug in the treatment of glaucoma [26, 28, 41-43]. Inhibition of hCA in the patients reduces the fluid pressure and change the fluid balance in the eyes. Besides, some recent reports indicated that treatment of some disorders such as ovarian, breast, colon and kidney cancers, epilepsy and edema are accelerated the process by hCA enzyme 
inhibitors [26, 28, 44-46]. Acetazolamide, a diuretic agent is most commonly used in the treatment of glaucoma. Unfortunately, long term use of this drug can affect the similar enzymes in the different tissues and cause side effects such as liver and kidney damage. Thus, we focused on candidate molecules of $A$. dracunculus herb that could be used in the treatment of glaucoma. According to the results obtained in this study, the compounds isolated from tarragon may be proposed as agent in the treatment of glaucoma. These results concluded that the A. dracunculus molecules except for trans-anethole (1) in particular compound 6 are the potential natural candidate molecules for the treatment of glaucoma.

A carbonic anhydrase enzyme catalyzes transformation of $\mathrm{CO}_{2}$ to bicarbonate ion and proton. There is a zinc ion $\left(\mathrm{Zn}^{2+}\right)$, which is necessary for catalysis in the active site of most carbonic anhydrase. The several pathological processes containing transformation of $\mathrm{CO}_{2}$ to bicarbonate ion, is involved with carbonic anhydrase reaction. For the remediation of those pathological processes, carbonic anhydrase reactions are inhibited by therapeutical agents. Sulphonamides, sulphamates and sulphamides are compounds known as carbonic anhydrase inhibitors. These compounds bind to the zinc ion of in the active area of carbonic anhydrase. Acetazolamide is a classical and effective sulphonamide hCA inhibitor for systemic therapy of glaucoma.
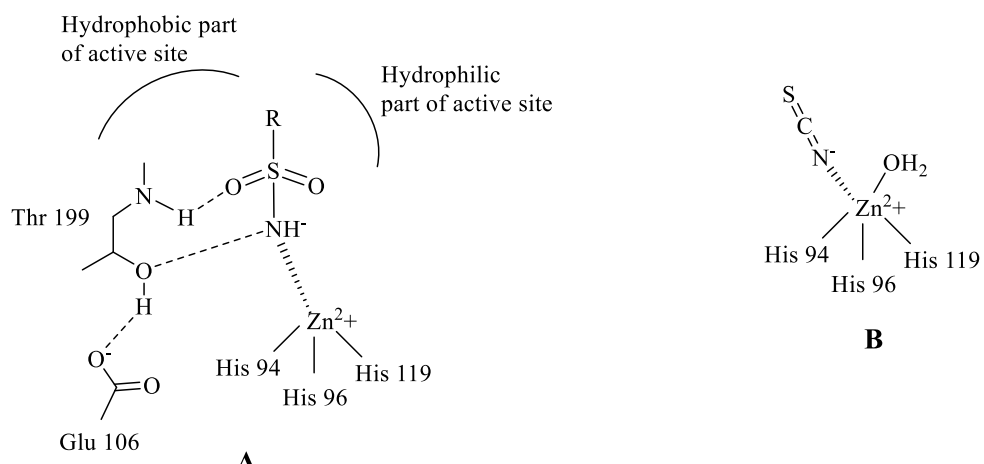

B

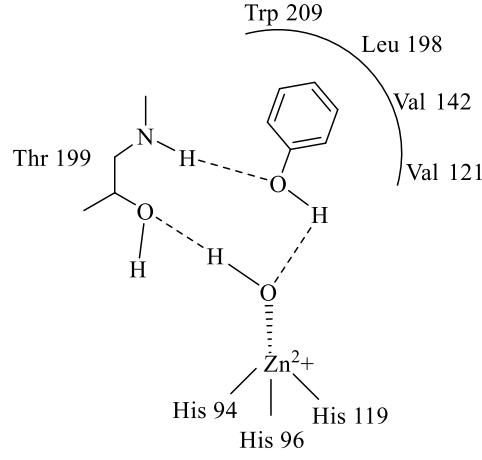

C

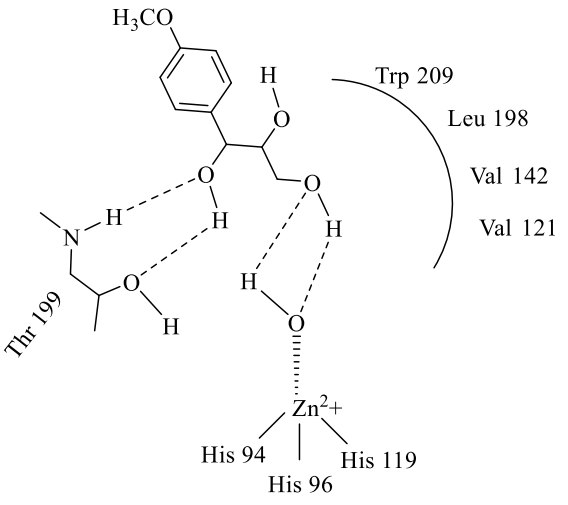

D

Figure 2. A: hCA enzyme binding sulfonamides figure. B: hCA binding inorganic anion model. C: Phenol hCA the zinc-bound water / hydroxide ion. D: Represented binding figure of hCA with compound $\mathbf{6}$. Hydrogen bonds are represented as dashed lines. All these binding models have been proven by means of $\mathrm{X}$-ray crystallography on enzyme-inhibitor adducts.

Glaucoma is a chronical and degenerative eye disease, qualified by high intraocular pressure. The main component of aqueous humor is identified as sodium bicarbonate [26, 47]. hCA enzymes responsible for the bicarbonate secretion in the front uvea of the eye. The sulphonamide hCA inhibitors reduce the rate of bicarbonate in the physiological treatment of glaucoma. In this context, the compound $\mathbf{6}$ which showed the highest inhibitory effect reduces bicarbonate formation inhibiting to carbonic anhydrate reaction. The possible interactions between hCA and compound 6 were shown in the Figure 2 [48].

In this study, pure A. dracunculus metabolites show inhibitory effect on the hCA I and II isozymes due to functional groups such as $-\mathrm{OCH}_{3},-\mathrm{CH}_{3}$ and $-\mathrm{OH}$ existing in their aromatic structure. Our results demonstrate possible new CA inhibitors of interest in addition to the much-used sulfamides/sulfamates/sulfonamides. However, compounds that different chemical-structure showed 
effective hCA I and II inhibitory activities in the low $\mathrm{IC}_{50}$ values [49]. Our results indicate that these compounds can be used as potent inhibitors.

In conclusion, the extracts of $A$. dracunculus and its pure metabolites (compounds 1-6) showed enzyme inhibitory effects on the hCA I and II isozymes. These results pointed out the A. dracunculus herb and its pure compounds 1-6 may have beneficial potentials in the treatment of glaucoma. In particular, among the metabolites, 1-(4'-methoxyphenyl)-1,2,3-trihydroxypropane (6) had the highest inhibitory effect on the hCA isozymes and its $\mathrm{IC}_{50}$ values on hCA I and II isozymes were also lower than those of acetazolamide. Our results concluded that compound $\mathbf{6}$ is a potential natural agent may be use in the glaucoma therapy as well as edema and epilepsy in humans. In addition to these results, studies on toxicity of A. dracunculus should be made in the future.

\section{Acknowledgments}

This study was part of the master's thesis performed by Bayram Yurtvermez, Ağrı Ibrahim Çeçen University, Graduate School of Natural and Applied Sciences.

\section{Supporting Information}

Supporting Information accompanies this paper on http://www.acgpubs.org/journal/records-ofnatural-products

\section{ORCID}

Bayram Yurtvermez: 0000-0001-9726-3672

Tuba Aydin: 0000-0002-7653-6480

Murat Şentürk: 0000-0002-9638-2896

Cavit Kazaz: 0000-0002-5249-0895

Ahmet Çakır: 0000-0003-1672-1438

\section{References}

[1] D. Obolskiy, I. Pischel, B. Feistel, N. Glotov and M. Heinrich (2011). Artemisia dracunculus L. (Tarragon): A critical review of its traditional use, chemical composition, pharmacology, and safety, J. Agr. Food Chem. 59, 11367-11384.

[2] A. Karimi, J. Hadian, M. Farzaneh and A. Khadivi-Khub (2015). Evaluation of genetic variability, rust resistance and marker-detection in cultivated Artemisia dracunculus from Iran, Gene 554, 224-232.

[3] S. Kordali, R. Kotan, A. Mavi, A. Cakir, A. Ala and A. Yildirim (2005). Determination of the chemical composition and antioxidant activity of the essential oil of Artemisia dracunculus and of the antifungal and antibacterial activities of Turkish Artemisia absinthium, A. dracunculus, Artemisia santonicum, and Artemisia spicigera essential oils, J. Agr. Food Chem. 53, 9452-9458.

[4] A.M. Aglarova, I.N. Zilfikarov and O.V. Severtseva (2008). Biological characteristics and useful properties of tarragon (Artemisia Dracunculus L.) (Review), Pharm. Chem. J. 42, 81-86.

[5] Z. Guvenalp, H. Ozbek, B. Dursunoglu, H. Yuca, S. Gozcu, Y.M. Cil, C. Kazaz, K. Kara and O.L. Demirezer (2017). alpha-Amylase and alpha-glucosidase inhibitory activities of the herbs of Artemisia dracunculus L. and its active constituents, Med. Chem. Res. 26, 3209-3215.

[6] M.A. Zarasvand, M. Madani and M. Modaresi (2016). The Effect of Hydroalcoholic Extract of Artemisia dracunculus L. (Tarragon) on Candida albicans Infection in Mice, Jundishapur J. Nat. Ph. 11, e29911.

[7] H. Mumivand, M. Babalar, L. Tabrizi, L.E. Crake, M. Shokrpour and J. Hadian, (2017). Antioxidant properties and principal phenolic phytochemicals of Iranian tarragon (Artemisia dracunculus L.) accessions, Hortic. Environ. Biote. 58, 414-422.

[8] R. Rezaei, K. Hazrati Tappe, S. Seyyedi and P. Mikaili (2017). The Anti-leishmanial efficacy of Artemisia dracunculus ethanolic extract in vitro and its effects on IFN-gamma and IL-4 Response, Iran J. Parasitol. 12, 398-407.

[9] S.M.A. Froushani, L. Zarei, H.E.G. Ghaleh and B.M. Motlagh (2016). Estragole and methyl-eugenol-free extract of Artemisia dracunculus possesses immunomodulatory effects, Avicenna J. Phytomedi. 6, 526-534. 
[10] M. Mendez-del Villar, A.M. Puebla-Perez, M.J. Sanchez-Pena, L.J. Gonzalez-Ortiz, E. Martinez-Abundis and M. Gonzalez-Ortiz (2016). Effect of Artemisia dracunculus administration on glycemic control, insulin sensitivity, and insulin secretion in patients with impaired glucose tolerance, J. Med. Food 19, 481-485.

[11] A. Eidi, S. Oryan, J. Zaringhalam and M. Rad (2016). Antinociceptive and anti-inflammatory effects of the aerial parts of Artemisia dracunculus in mice, Pharm. Biol. 54, 549-554.

[12] G. Jalilzadeh-Amin and B.M. Qarehdarvishlu (2015). Effects of Artemisia dracunculus essential oil on diarrhea and intestinal transit time in rat gastrointestinal tract, Physiol. Pharmacol. 18, 416-428.

[13] L. Hong and S.H. Ying (2015). Ethanol extract and isolated constituents from Artemisia dracunculus inhibit esophageal squamous cell carcinoma and induce apoptotic cell death, Drug Res. 65, 101-106.

[14] B. Dursunoglu, H. Yuca, S. Gozcu, H. Ozbek, Z. Guvenalp and L.O. Demirezer (2016). In vitro alphaamylase and alpha-glucosidase inhibitory activity of extracts and compounds from cultivated Artemisia dracunculus, Planta Med. 82, S1-S381.

[15] R.S. Pappas and G. Sturtz (2001). Unusual alkynes found in the essential oil of Artemisia dracunculus L. var. dracunculus from the Pacific Northwest, J. Essent. Oil Res. 13, 187-188.

[16] M. Sayyah, L. Nadjafnia and M. Kamalinejad (2004). Anticonvulsant activity and chemical composition of Artemisia dracunculus L. essential oil. J. Ethnopharmacol. 94, 283-287.

[17] M. Talbi, B. Saadali, D. Boriky, L. Bennani, M. Elkouali and T. Ainane (2016). Two natural compounds - a benzofuran and a phenylpropane from Artemisia dracunculus, J. Asian Nat. Prod. Res. 18, 724-729.

[18] Z. Brahmi, T. T. Katho, R. Hatsumata, A. Hiroi, N. Miyakawa, E. Yakou, K. Sugaya, J. Onose and N. Abe (2012). Effective cytochrome P450 (CYP) inhibitors isolated from tarragon (Artemisia dracunculus), Biosci. Biotech. Bioch. 76, 1028-1031.

[19] M. Yamada, K. Nakamura, T. Watabe, O. Ohno, M. Kawagoshi, N. Maru, N. Uotsu, T. Chiba, K. Yamaguchi and D. Uemura (2011). Melanin biosynthesis inhibitors from tarragon Artemisia dracunculus, Biosci. Biotech. Bioch. 75, 1628-1630.

[20] D.M. Ribnicky, P. Kuhn, A. Poulev, S. Logendra, A. Zuberi, W.T. Cefalu and I. Raskin (2009). Improved absorption and bioactivity of active compounds from an anti-diabetic extract of Artemisia dracunculus L., Int. J. Pharmaceut. 370, 87-92.

[21] D. Govorko, S. Logendra, Y. Wang, D. Esposito, S. Komarnytsky, D. Ribnicky, A. Poulev, Z. Wang, W.T. Cefalu and I. Raskin (2007). Polyphenolic compounds from Artemisia dracunculus L. inhibit PEPCK gene expression and gluconeogenesis in an H4IIE hepatoma cell line, Am. J. Physiol-Endoc. M. 293, E1503E1510.

[22] M.H. Navarro-Salcedo, J.I. Delgado-Saucedo, V.H. Siordia-Sanchez, L.J. Gonzalez-Ortiz, G.A. CastilloHerrera and Puebla-Perez AM (2017). Artemisia dracunculus extracts obtained by organic solvents and supercritical $\mathrm{CO}_{2}$ produce cytotoxic and antitumor effects in mice with L5178Y lymphoma, J. Med. Food. 20, 1076-1082.

[23] S.W. Eisenman, H.R. Juliani, L. Struwe and J.E. Simon (2013). Essential oil diversity in North American wild tarragon (Artemisia dracunculus L.) with comparisons to French and Kyrgyz tarragon, Ind. Crop. Prod. 49, 220-232.

[24] T. Kamarainen-Karppinen, A. Makinen, S. Kolehmainen, A. Hamalainen, K. Laine, A. Hohtola, S. Mattila and A.M. Pirttila (2008). Overwintering, chemical variation, and genetic diversity in three vegetatively propagated lines of French tarragon (Artemisia dracunculus var. sativa), J. Hortic. Sci. Biotechnol. 83, 765769.

[25] M. Szczepanik, M. Walczak, B. Zawitowska, M. Michalska-Sionkowska, A. Szumny, C. Wawrzenczyk and M.S. Brzezinska (2018). Chemical composition, antimicromicrobial activity and insecticidal activity against the lesser mealworm Alphitobius diaperinus (Panzer) (Coleoptera: Tenebrionidae) of Origanum vulgare L. ssp. hirtum (Link) and Artemisia dracunculus L. essential oils, J. Sci. Food Agric. 98, 767-774.

[26] T. Gokcen, M. Al, M. Topal, I. Gulcin, T. Ozturk and A. C. Goren (2017). Synthesis of some natural sulphonamide derivatives as carbonic anhydrase inhibitors, Org. Commun. 10 (1), 15-23.

[27] M. Hilvo, L. Baranauskiene, A.M. Salzano, A. Scaloni, D. Matulis, A. Innocenti, A. Scozzafava, S.M. Monti, A. Di Fiore, G. De Simone, M. Lindfors, J. Janis, J. Valjakka, S. Pastorekova, J. Pastorek, M.S. Kulomaa, H.R. Nordlund, C.T. Supuran and S. Parkkila (2008). Biochemical characterization of CA IX, one of the most active carbonic anhydrase isozymes, J. Biol. Chem. 283, 27799-27809.

[28] L. Polat Köse and İ. Gulcin (2017). Inhibition effects of some lignans on carbonic anhydrase, acetylcholinesterase and butyrylcholinesterase enzymes, Rec. Nat. Prod.. 11(6), 558-561.

[29] D. Ekinci, H. Cavdar, O. Talaz, M. Senturk and C.T. Supuran (2010). NO-releasing esters show carbonic anhydrase inhibitory action against human isoforms I and II, Bioorg. Med. Chem. 18, 3559-3563.

[30] S. Isik, D. Vullo, S. Durdagi, D. Ekinci, M. Senturk, A. Cetin, E. Senturk and C.T. Supuran (2015). Interaction of carbonic anhydrase isozymes I, II, and IX with some pyridine and phenol hydrazinecarbothioamide derivatives, Bioorg. Med. Chem. Lett. 25, 5636-5641. 
[31] I. Fidan, R.E. Salmas, M. Arslan, M. Senturk, S. Durdagi, D. Ekinci, E. Senturk, S. Cosgun and C.T. Supuran (2015). Carbonic anhydrase inhibitors: Design, synthesis, kinetic, docking and molecular dynamics analysis of novel glycine and phenylalanine sulfonamide derivatives, Bioorg. Med. Chem. 23, 7353-7358.

[32] J.A. Verpoorte, S. Mehta and J.T. Edsall (1967). Esterase activities of human carbonic anhydrases B and C, J. Biol. Chem. 242, 4221-4229.

[33] S.W. Lee, G. Li, K.S. Lee, D.K. Song and J.K. Son (2003). A new phenylpropanoid glucoside from the fruits of Illicium verum, Arch. Pharm. Res. 26, 591-593.

[34] B.A. Behbahani, F. Shahidi, F.T. Yazdi, S.A. Mortazavi and M. Mohebbi (2017). Antioxidant activity and antimicrobial effect of tarragon (Artemisia dracunculus) extract and chemical composition of its essential oil, J. Food. Meas. Charact. 11, 847-863.

[35] D.M. Ribnicky, A. Poulev, M. Watford, W.T. Cefalu and I. Raskin (2006). Antihyperglycemic activity of Tarralin (TM), an ethanolic extract of Artemisia dracunculus L., Phytomedicine 13, 550-557.

[36] Z.Q. Wang, D. Ribnicky, X.H. Zhang, I. Raskin, Y.M. Yu and W.T. Cefalu (2008). Bioactives of Artemisia dracunculus L. enhance cellular insulin signaling in primary human skeletal muscle culture, Metabolism. 57, S58-S64.

[37] M. Benli, I. Kaya and N. Yigit (2007). Screening antimicrobial activity of various extracts of Artemisia dracunculus L., Cell Biochem. Funct. 25, 681-686.

[38] L. Shahriyary and R. Yazdanparast (2007). Inhibition of blood platelet adhesion, aggregation and secretion by Artemisia dracunculus leaves extracts, J. Ethnopharmacol. 114, 194-198.

[39] I. Kheterpal, P. Scherp, L. Kelley, Z .Wang, W. Johnson, D. Ribnicky and W.T. Cefalu (2014). Bioactives from Artemisia dracunculus L. enhance insulin sensitivity via modulation of skeletal muscle protein phosphorylation, Nutrition. 30, S43-S51.

[40] S. Aggarwal, G. Shailendra, D.M. Ribnicky, D. Burk, N. Karki and M.S.Q.X. Wang (2015). An extract of Artemisia dracunculus L. stimulates insulin secretion from beta cells, activates AMPK and suppresses inflammation, J. Ethnopharmacol. 170, 98-105.

[41] A.M. Alafeefy, F. Carta, M. Ceruso, A.M.S. Al-Tamimi, A.A. Al-Kahtani and C.T. Supuran (2016). Development of 3-(4-aminosulphonyl)-phenyl-2-mercapto-3-H-quinazolin-4-ones as inhibitors of carbonic anhydrase isoforms involved in tumorigenesis and glaucoma, Bioorg. Med. Chem. 24, 1402-1407.

[42] S. Carradori, A. Mollica, C. De Monte, A. Granese and C.T. Supuran (2015). Nitric oxide donors and selective carbonic anhydrase inhibitors: A dual pharmacological approach for the treatment of glaucoma, cancer and osteoporosis, Molecules 20, 5667-5679.

[43] K. Gugleta (2010). Topical carbonic anhydrase inhibitors and visual function in glaucoma and ocular hypertension, Curr. Med. Res. Opin. 26, 1255-1267.

[44] J. Meehan, C. Ward, C.T. Supuran, S.P. Langdon and I. Kunkler (2013). The effects of novel carbonic anhydrase inhibitors on the proliferation and invasion of breast and ovarian cancer cells, J. Pathol. 231, 3636.

[45] S.K. Parks, Y. Cormerais, J. Durivault and J. Pouyssegur (2017). Genetic disruption of the pH(i)-regulating proteins $\mathrm{Na}+\mathrm{H}+$ exchanger 1 (SLC9A1) and carbonic anhydrase 9 severely reduces growth of colon cancer cells, Oncotarget. 8, 10225-10237.

[46] S. Signoretti, M. Regan and M. Atkins (2008). Carbonic anhydrase IX as a predictive biomarker of response to kidney cancer therapy, Bju. Int. 101, 31-35.

[47] A. Scozzafava, A. Mastrolorenzo and C.T. Supuran (2006). Carbonic anhydrase inhibitors and activators and their use in therapy, Expert Opin. Ther. Pat. 16, 1627-1664.

[48] C.T. Supuran (2016). How many carbonic anhydrase inhibition mechanisms exist, J. Enzym. Inhib. Med. Ch. 31, 345-360.

[49] S. Durdagi, N. Korkmaz, S. Isik, D. Vullo, D. Astley, D. Ekinci, R.E. Salmas, M. Senturk and C.T. Supuran (2016). Kinetic and docking studies of cytosolic/tumor-associated carbonic anhydrase isozymes I, II and IX with some hydroxylic compounds, J. Enzym. Inhib. Med. Ch. 31, 1214-1220.

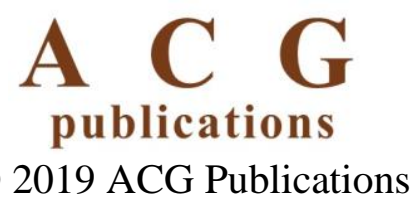

